\title{
CORONAVIRUS DISEASE 2019 (COVID-19): A CHALLENGE OF PROTECTING THE GENERAL POPULATION AND HEALTH-CARE WORKERS
}

\section{Akhtar Sherin ${ }^{1 \otimes}$}

THIS ARTICLE MAY BE CITED AS: Sherin A. Coronavirus disease 2019 (COVID-19): a challenge of protecting the general population and healthcare workers. Khyber Med Univ J 2020;12(I):4-5. DOI:10.35845/kmuj. 2020.20224 .

Year 2020 proved to be a nightmare for global health and economy by widespread outbreak of coronavirus across the globe. First reported at Wuhan, the capital city of Hubei province of China as pneumonia of unknown cause on December 31, 2019.' Within a week, a novel coronavirus was isolated from patients in Wuhan, ${ }^{2}$ and within next month WHO declared it as "Public Health Emergency of International Concern". WHO named this disease as new coronavirus disease 2019 (COVID-19) on February II, 2020.' On March II, 2020, WHO declared COVID-19 as pandemic. ${ }^{3}$ As per WHO COVID-19 situation Report-70, total confirmed cases of COVID-19 until March 30, 2020 were 693224 and deaths due to COVID-19 were 33106 in the world. ${ }^{4}$ COVID- 19 has affected more than 200 countries and regions in a very short period. In Pakistan, since the confirmation of first case on February 26, 2020; the total confirmed cases of COVID-19 are I,865 and 25 deaths till March 31, 2020.

The unprecedented pandemic of COVID-19 led to a panic situation around the world. The major issue is to prevent the spread of corona virus to other regions. Recent reports have confirmed the person-to-person transmission of COVID-19, leading to affect the immediate contacts of patients including health-care workers. People traveling from the affected areas are the potential source of disease transmission. ${ }^{6,7}$ This led to international and domestic travel and/or trade restriction in affected areas and quarantine for returning travelers by various countries. To ensure social distancing among common people, lock-down of provinces, regions and cities was executed by various countries. WHO recommends public health education regarding promotion of personal hygiene like washing hands, use of sanitizers, ensuring cough etiquette and avoiding crowded places (religious places, markets, etc) as preventive strategy. However, decision regarding lockdown and travel restriction is very difficult due to financial reasons and to maintain the supply-chain of essential goods and food items. Delay in decision-making regarding such actions by some countries resulted in rapid spread of COVID-19 with increased morbidity and mortality. Italy $(\mathrm{n}=1078 \mathrm{I})$ and Spain $(n=6528)$ are such countries with highest number of COVID-19 related deaths so far. $^{4}$ In resource-poor countries like Pakistan, the decision regarding complete lock-down and social distancing could be very challenging due to socioeconomic and other reasons. Preparedness and response of the country to such pandemics is critical for disease surveillance, diagnostics workup, clinical management, prevention and control of infection and risk communication.

COVID-19 is caused by a novel coronavirus (severe acute respiratory syndrome coronavirus-2) and until now, there is no vaccine or cure available for it. ${ }^{8,9}$ Majority of patients are with mild to moderate severity and have good survival. However, critically ill patients require intensive care and mechanical ventilation for hypoxemic respiratory
I. Chief Editor, Khyber Medical University Journal and Professor of Medicine, Khyber Medical University Institute of Medical Sciences (KMU-IMS), Kohat, Pakistan. Email『:akhtarsherin@yahoo.com

failure. Mortality in these patients is very high even in best centres of the world.' Availability of necessary equipment for critically ill COVID-19 is a global issue and shortage of ventilators and other equipment has been reported from USA as well. ${ }^{10}$ In developing countries like Pakistan, the shortage of high dependency units, fully equipped intensive care units and ventilators is a main challenge for governments. Availability of intensivist and trained staff for operating ventilators is another major issue in managing seriously ill COVID-19 patients in developing countries.

Another major challenge faced during coping with COVID-19 pandemic was ensuring the safety of frontline healthcare workers. So far, more than 3300 health-care providers were infected with COVID-19 at China" and more than 60 doctors died in Italy. ${ }^{12}$ In Pakistan, Dr. Osama Riaz, a young doctor who was infected with COVID19 during handling patients died at Gilgit. ${ }^{13}$ These frontline health-care workers are fighting "unarmed" against COVID-19. Health-care workers should be fully equipped with adequate number of personal protection equipment including N95 respirator and surgical masks, gloves, face shields, goggles, gowns and hand sanitizers. Proper triage system should be established at every health-care facility for screening of COVID-19 patients. Number of trained frontline health-care workers should be increased to reduce the overburden and exhaustion of the health workforce.

This is a critical time for all stakeholders of the government to establish a national command and control system to combat COVID-I9 and similar outbreaks. A substantial increase in current health budget is crucial to meet the requirements of national health related issues. Government must prioritize the health and rationalize the number of beds per 1000 people in 
hospitals and intensive care units as per international requirements. Specialised training in field of intensive care and other relevant specialties must be ensured to doctors, nurses and paramedics to provide and maintain high-quality critical care to patients. Community education regarding various Public health issues and personal hygiene through electronic and social media as well as at school level can prove vital in prevention of such outbreaks.

\section{REFERENCES}

I. World Health Organization. Rolling updates on coronavirus disease (COVID-19): Updated 27 March 2020. [Accessed on: March 27, 2020]. Available from URL: https://www. who.int/emergencies/diseases/novelcoronavirus-2019/events-as-theyhappen.

2. Wang C, Horby PW, Hayden FG, Gao GF. A novel coronavirus outbreak of global health concern. Lancet 2020 Feb I5;395(I 0223):470-3. DOI: 10.1016/50|40-6736(20)30185-9.

3. World Health Organization (WHO). WHO Director-General's opening remarks at the media briefing on COVID-19 - II March 2020. 2020. [Accessed on: March 30, 2020].
Available from URL: https://www. who.int/dg/speeches/detail/whodirector-general-s-opening-remarksat-the-media-briefing-on-covid- 19 I I-march-2020.

4. World Health Organization. Coronavirus disease 2019 (COVID19) Situation Report - 70. [Accessed on: March 30, 2020]. Available from URL: https://www.who.int/ docs/default-source/coronaviruse/ situation-reports/20200330-sitrep70-covid-19.pdf?sfvrsn=7e0fe3f8_2.

5. Government of Pakistan. Coronavirus in Pakistan. March 30, 2020. [Accessed on: March 30, 2020]. Available from URL: http://covid. gov.pk/stats/pakistan

6. Guo YR, Cao QD, Hong ZS, Tan YY, Chen SD, Jin HJ, et al. The origin, transmission and clinical therapies on coronavirus disease 2019 (COVID19) outbreak - an update on the status. Military Med Res 2020; 7: I I. DOI: I0.1 I86/s40779-020-00240-0.

7. Singhal T. A Review of Coronavirus Disease-2019 (COVID-19). Indian J Pediatr 2020; 87: 28I-6. DOI: I0.1 | 86/s40779-020-00240-0.

8. Cao B, Wang Y, Wen D, Liu W, Wang J, Fan $G$, et al. A trial of lopinavirritonavir in adults hospitalized with severe Covid-19. N Engl J Med 2020
Mar 18. DOI: 10.1056/NEJMoa 2001282.

9. Bhatraju PK, Ghassemieh BJ, Nichols $M, K i m R$, Jerome KR, Nalla $A K$, et al. Covid- 19 in Critically III Patients in the Seattle Region - Case Series. N Engl Med 2020 March 30. DOI: I0. I056/NEJMoa2004500.

10. Ranney ML, Griffeth $V$ and Jha AK. Critical Supply Shortages - The Need for Ventilators and Personal Protective Equipment during the Covid-19 Pandemic. N Engl J Med 2020 Mar 25. DOI: 10.1056/ NEJMp2006 I4I.

II. The Lancet. COVID-19: protecting health-care workers. Lancet 2020 Mar 21;395(I0228):922. DOI: 10.1016/S0140-6736(20)30644-9.

12. Chustecka Z. More than 60 doctors in Italy have died in COVID-I9 Pandemic. Medscape. [Accessed on: March 30, 2020]. Available from URL: https://www.medscape.com/viewarti cle/927753.

13. Pakistani 'hero' doctor who led fight against coronavirus dies. Gulf Today. Marh 23, 2020. [Accessed on: March 30, 2020]. Available from URL: https://www.gulftoday.ae/news/2020/ 03/23/pakistani-hero-doctor-wholed-fight-against-coronavirus-dies.

CONFLICT OF INTEREST
Authors declared no conflict of interest
GRANT SUPPORT AND FINANCIAL DISCLOSURE
NIL

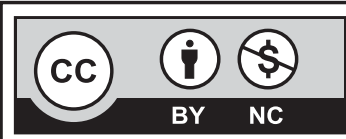

This is an Open Access article distributed under the terms of the Creative Commons Attribution-Non Commercial 2.0 Generic License.

KMUJ web address: www.kmuj.kmu.edu.pk Email address: kmuj@kmu.edu.pk 